\title{
SHOOTING PARAMETERS OF BIATHLETES IN VARIOUS AGE GROUPS IN 2011-2012 WORLD CHAMPIONSHIPS
}

Lina Kreivènaitė

Lithuanian University of Educational Sciences, Vilnius, Lithuania

\begin{abstract}
Research background and hypothesis. Physical fitness problems in biathlon are quite extensively discussed, but biathlon shooting in Lithuania is not analyzed enough. The special literature lacks information about the shooting parameters that leaders demonstrate in the world biathlon championships. Moreover, shooting parameters in different age and gender groups have not been analyzed enough. The hypothesis that shooting parameters in adult, youth and junior age group biathletes would differ was tested.

Research aim. The aim of our study was to analyze shooting parameters of biathletes in various age groups in 2011-2012 world championships and reveal fundamental differences in the aspects of age and gender.

Research methods. Research participants were youths (age: 17-18 years), juniors (age: 19-20 years) and adults (age: 21-41 years), male and female biathletes. The number of subjects was 2175. Descriptive statistical methods were used for data analysis.

Research results. Data analysis revealed the main differences in shooting parameters between adult, junior and youth groups, male and female biathletes. Also, comparison of shooting parameters between biathletes in various age groups and leaders in the same group was carried out.

Discussion and conclusions. Our research revealed that the highest shooting accuracy was observed in adult male and female biathlete groups $(\mathrm{p}<0.025)$. The shooting accuracy of junior and youth female biathletes was higher than that in the junior and youth male groups $(\mathrm{p}<0.05)$. The longest average shooting time was in youth group $(p<0.001)$. The shooting time of biathletes in adult group was the shortest. We found that male biathletes in various age groups performed shots in less time compared to female biathletes $(p<0.05)$. Research results revealed that shooting parameters among leaders statistically significantly differed comparing them with the average shooting parameters in the group $(\mathrm{p}<0.05)$.
\end{abstract}

Keywords: biathlon, shooting accuracy, shooting time.

\section{INTRODUCTION}

$\mathrm{B}$ iathlon is complex winter sport which combines cross-country skiing with rifle marksmanship. Cyclical cross-country load in biathlon combines with acyclic actions in the fire range which requires complicated movement coordination (Pöhlmann, 1986). It is known that skiing time has bigger influence on final result in comparison with shooting efficiency in biathlon (Cholewa et. al., 2005). However, final competition results and success in biathlon are decided not only upon the ability to ski fast but also the ability to shoot accurately (Skernevičius et al., 2005). Also, a biathlete makes big difference being able to change in competition in skiing - shooting activities and control psychical tension, especially in a shooting range (Сорокина, 2010).

Shooting in biathlon is a complicated motor activity which requires position stability, high concentration and psychomotor skill levels with preliminary rapid preparation actions to assure fast and accurate shooting in both positions. Moreover, shooting in biathlon is highly influenced by various internal and external factors. The main internal factors are psychophysical, technical, tactical and 
psychological. The main external factors are social, climatic and factors which are related to sports equipment (Hofman et al., 1992; Nitzsche, 1998; Grebot et al., 2003; Sattlecker et al., 2006; Grebot, Burtheret, 2007). Only a few studies have been directed towards shooting tasks in biathlon which mainly are concerned with physiological factors. From a scientific point of view it is important to analyse statistically the results of shooting obtained during recent world biathlon championships.

\section{RESEARCH METHODS}

Research was carried out by analysing official protocols of youth, junior and adult biathletes' shooting parameters in 2011-2012 world biathlon championships. The shooting parameters analysed were shooting accuracy (\%) and shooting time (s).

For data analysis we chose biathletes who were participating in youth (age: 17-18 years) 691, junior (age: 19-20 years) 545 and adult (age: $21-41$ years) 939 groups, men and women. They were named as subjects. The overall number of subjects in our study was 2175 .

The study was accomplished by analysing official protocols of youth, junior and adult biathlon world championships in 2011-2012 year (www. biathlonworld.com, www.Hora2000.com).

Statistical analysis. All the data were expressed as average (x), standard error (Sx), standard deviation (S) and variance (V) of the mean. Hypothesis concerning the difference between means was verified using Stjudent $t$ test for independent and dependent variables. The difference between the means was regarded as statistically significant when error probably with respect to criteria was $\mathrm{p}<0.05$.

\section{RESEARCH RESULTS}

Data analysis revealed that overall shooting accuracy of adult female group amounted to $76.8 \%$. The shooting accuracy of biathletes in junior female group was $71.8 \%$, while for woman in the youth group $-70.6 \%$. Testing shooting accuracy in various age male groups educed that adult biathletes reached $77.4 \%$ shooting accuracy. Also, shooting accuracy of junior male biathletes was $70.4 \%$. Biathletes in youth male group reached $67.3 \%$ of the shooting accuracy level (Table 1).

The analyses of the results of shooting time revealed that adult women biathletes spent on
Table 1. Shooting accuracy of various age groups, men $(M)$ and women $(\mathrm{W})$, in prone and stand positions

Note. Sx - standard error, $\mathrm{S}$ - standard deviation, $\mathrm{V}$ - variance of the mean; * - Biathletes who achieved $1^{\text {st }}-8^{\text {th }}$ places in youth women and adult men groups were considered as leaders. In other groups leaders' results calculation was based on data from biathletes who took $1^{\text {st }-3^{\text {rd }}}$ places.

Table 2. Shooting time of various age groups, men (M) and women $(\mathrm{W})$, in prone and stand positions

Note. $\mathrm{Sx}-$ standard error, $\mathrm{S}$ - standard deviation, $\mathrm{V}$ variance of the mean.

\begin{tabular}{|c|c|c|c|c|c|c|}
\hline Age group & \multicolumn{2}{|c|}{ Youth } & \multicolumn{2}{c|}{ Junior } & \multicolumn{2}{c|}{ Adult } \\
\hline Gender & M & W & M & W & M & W \\
\hline $\begin{array}{c}\text { Average of leaders' } \\
\text { accuracy (\%) }\end{array}$ & 87.5 & $88.8^{*}$ & 91.7 & 93.3 & $92.2^{*}$ & 95.8 \\
\hline Sx & 1.3 & 1.0 & 2.1 & 1.5 & 1.1 & 1.0 \\
\hline S & 2.2 & 2.8 & 3.6 & 2.6 & 3.2 & 3.1 \\
\hline V & 2.5 & 3.2 & 3.9 & 2.8 & 3.5 & 3.2 \\
\hline Average of group accuracy & 67.3 & 70.6 & 70.4 & 71.8 & 77.4 & 76.8 \\
\hline Sx & 1.4 & 1.5 & 1.4 & 1.4 & 1.2 & 1.2 \\
\hline S & 22.5 & 22.1 & 19.6 & 20.2 & 17.9 & 18.8 \\
\hline V & 33.4 & 31.2 & 28.4 & 28.5 & 23.2 & 24.8 \\
\hline
\end{tabular}

\begin{tabular}{|c|c|c|c|c|c|c|}
\hline Age group & \multicolumn{2}{|c|}{ Youth } & \multicolumn{2}{c|}{ Junior } & \multicolumn{2}{c|}{ Adult } \\
\hline Gender & M & W & M & W & M & W \\
\hline $\begin{array}{c}\text { Shooting time in prone } \\
\text { position (s) }\end{array}$ & 42.4 & 45.5 & 39.8 & 41.8 & 34.7 & 37.9 \\
\hline Sx & 0.8 & 0.9 & 0.7 & 0.7 & 0.4 & 0.4 \\
\hline S & 7.7 & 7.6 & 6.1 & 5.4 & 4.9 & 4.7 \\
\hline V & 18.2 & 16.7 & 15.4 & 13.1 & 14.1 & 12.5 \\
\hline $\begin{array}{c}\text { Shooting time in stand } \\
\text { position (s) }\end{array}$ & 37.2 & 41.3 & 34.7 & 39.9 & 31.4 & 34.9 \\
\hline Sx & 0.6 & 0.8 & 0.5 & 0.7 & 0.4 & 0.4 \\
\hline S & 6.3 & 6.8 & 4.9 & 5.5 & 4.7 & 3.9 \\
\hline V & 16.9 & 16.3 & 14.1 & 13.9 & 14.9 & 11.3 \\
\hline
\end{tabular}


average $36.4 \mathrm{~s}$ for a shot. Average shooting time of junior women biathletes was $40.8 \mathrm{~s}$. Also, youth women group reached the average shooting time of $43.4 \mathrm{~s}$. The data analysis of men group biathletes' shooting time showed that adult biathletes spent $33.1 \mathrm{~s}$ on shooting. Also, the analysis revealed that biathletes in junior male group demonstrated the shooting time of $37.3 \mathrm{~s}$ and youth male biathletes performed shots in $39.8 \mathrm{~s}$ (Table 2).

\section{DISCUSSION}

Scientists M. D. Hoffman et al. (1992), M. D. Hofman ansd G. M. Street (1992), K. Rundell and D. Bacharach (1995), B. Paugsachova (2000), F. Manfredini et al. (2002), J. Cholewa et al. (2005), B. Paugsachova et al. (2010) claim that the final result of the competition mostly depends on $\mathrm{VO}_{2}$ max and upper body muscle power of biathlete in skiing event, also shooting accuracy and time in shooting event. The study of J. Cholewa et al. (2004) obtained results which clearly indicated a decrease in the level of efficiency in shooting parameters in biathlon in the seasons of 1997-2003. However, K. Nitzsche's (1998) research on the shooting parameters in 1969-1996 seasons determined that the shooting parameters had a tendency to increase. Our study agrees with the previously mentioned thesis that success in shooting event is highly influenced by shooting accuracy and time because our data analysis revealed that biathletes who occupied leader positions demonstrated significantly higher shooting accuracy levels and shorter shooting time than their group on average $(\mathrm{p}<0.05)$ (Table 1, Figure 4).

The analysis of the research results showed that shooting parameters between various age group biathletes had statistically significant differences. Research revealed that the shooting accuracy in prone position was significantly higher than that in stand position among various age group women biathletes $(\mathrm{p}<0.01)$. Biathletes in adult women group showed a significantly better average shooting accuracy than junior $(\mathrm{p}<0.025)$ and youth group women $(\mathrm{p}<0.005)$, in both prone and stand shooting positions. Moreover, the shooting accuracy in stand position of junior women group biathletes was significantly higher than that of youth biathletes $(\mathrm{p}<0.05)$ (Figure 1).

The results obtained during the study showed that shooting accuracy in prone position was significantly higher than that in stand position among various age group men biathletes. Average shooting accuracy of adult men biathletes was significantly higher than that of junior $(\mathrm{p}<0.005)$ and youth men biathletes $(p<0.001)$. Also, the analysis revealed that junior men group biathletes demonstrated higher average shooting accuracy than youth biathletes $(\mathrm{p}<0.05)$ (Figure 2).

Results of A. Kryl (1987) and M. I. Shykunov (Шикунов, 1987) research revealed that average shooting time of adult group biathletes was $32.5 \mathrm{~s} \pm 0.36$ in prone and $30.2 \mathrm{~s} \pm 0.24$ in stand position. The analysis of our study established that the average time spent in shooting of biathletes in adult group was $36.3 \mathrm{~s} \pm 0.4$ was in prone and $33.2 \mathrm{~s} \pm 0.4$ in stand position (Figure 3). Although our data analysis revealed that shooting time was insignificantly longer than that in previous research of A. Kryl (1987) and M. I. Shykunov (Шикунов, 1987) it showed that shooting time was important for success in shooting event.

Our study showed that the longest shooting time was determined in youth group, while adult group

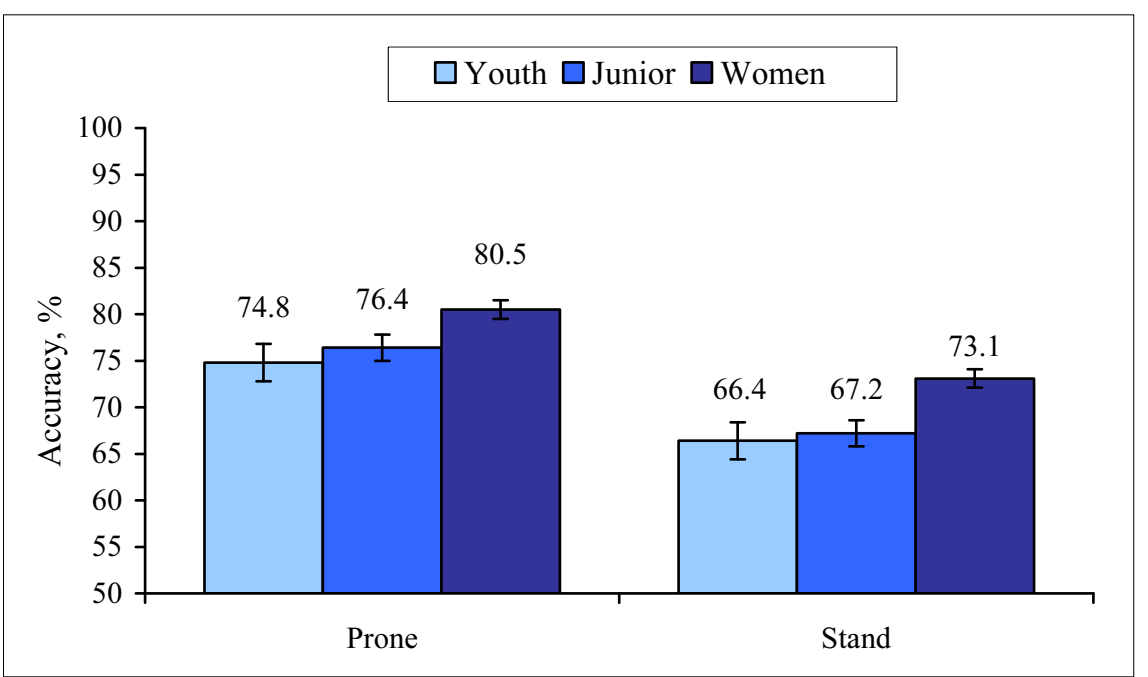

Figure 1. Shooting accuracy of various age group women biathletes, in prone and stand positions $(X \pm S x)$ 
Figure 2. Shooting accuracy of various age group men biathletes, in prone and stand positions $(\mathrm{X} \pm \mathrm{Sx})$

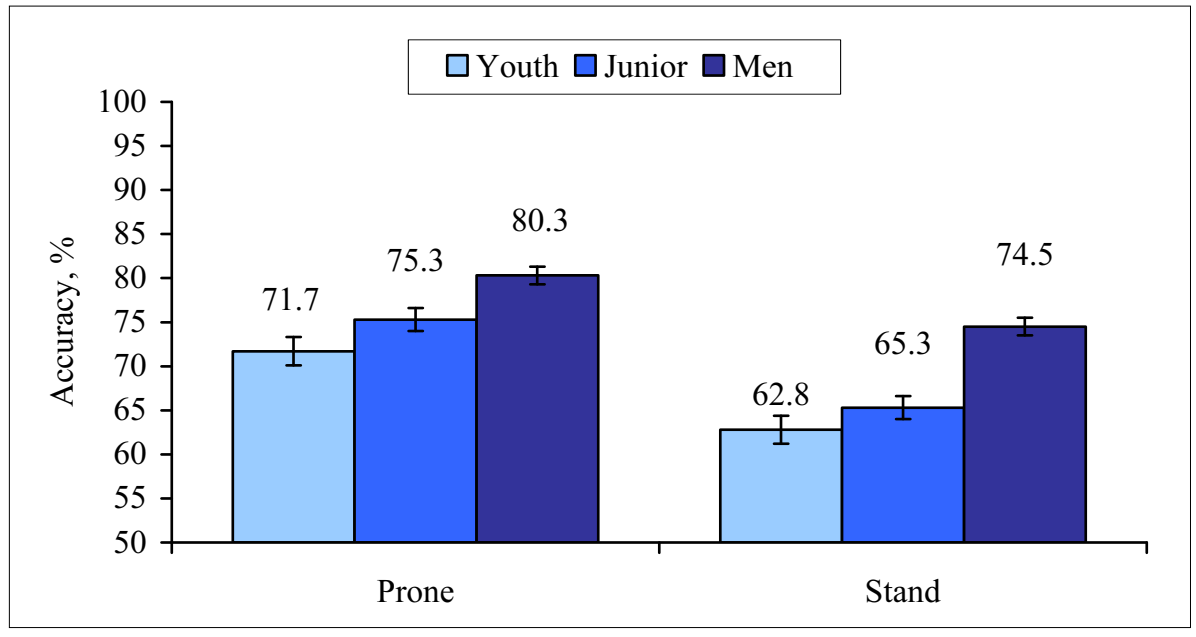

Figure 3. Average shooting time of various age groups, men and women $(X \pm S x)$
Figure 4. Average shooting time of leaders in various age groups, men and women $(X \pm S x)$
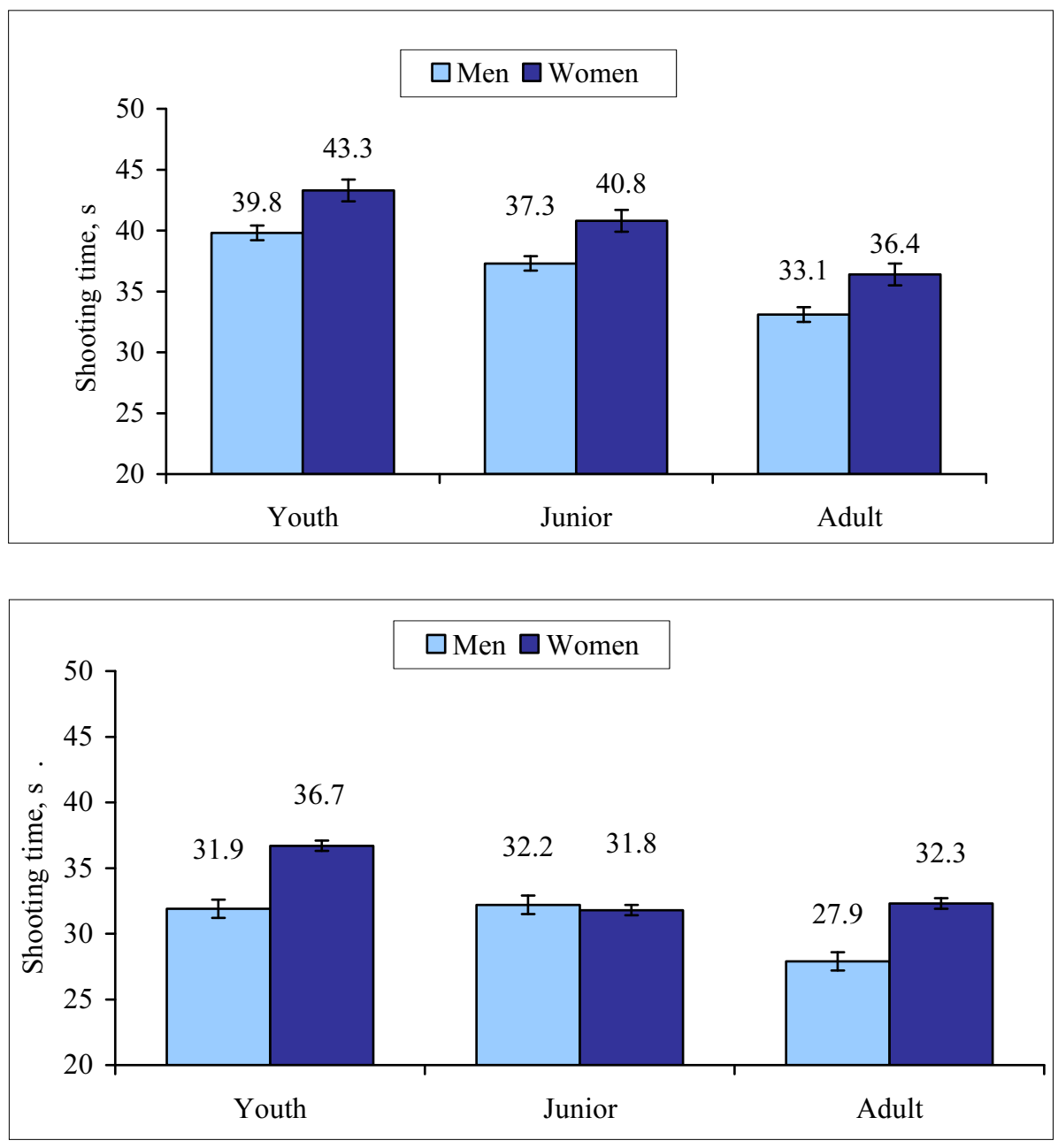

biathletes demonstrated the shortest shooting time $(\mathrm{p}<0.001)$. Adult male group showed the shortest average shooting time in both stand (31.4 s) and prone $(34.7 \mathrm{~s})$ positions. We found that male biathletes in various age group showed shorter shooting time than women biathletes in various age groups $(\mathrm{p}<0.005)$ (Figure 3$)$. We observed a tendency that shooting time in prone position was longer than that in stand position $(\mathrm{p}<0.05)$.
We compared the shooting timeresults in various age groups with the shooting time of leaders in the same groups. We found that biathletes who took award winning places demonstrated significantly shorter shooting time than of the biathletes in their groups $(p<0.05)$. Average shooting time of leaders in adult men and women group were $30.9 \mathrm{~s} \pm 1.1$ in prone and $29.3 \mathrm{~s} \pm 0.9$ in stand positions (Figure 4). 
Some scientists (Pustovrh et al., 1995; Cholewa et al., 2004; Cholewa et al., 2005; Sattlecker et al., 2006) found no shooting significance to final competition results. However, our research revealed the tendency that the shooting time of biathletes who took leader places had significantly differed from the average shooting time of their group. This difference was most distinct in junior and youth groups.

Our research results suggest that shooting parameters in modern biathlon are becoming increasingly important. However, there is no information how to evaluate shooting parameters. For this reason, further studies should be carried out to construct reference assessment scales for shooting parameters.

\section{CONCLUSIONS AND PERSPECTIVES}

1 The highest shooting accuracy was determinate in adult male and female groups of biathletes. The average shooting accuracy level between youth and junior groups did not differ statistically significantly.

2. The longest average shooting time was in youth group. The shortest time of shooting was observed in adult group of biathletes. The shooting time of men in various age groups was shorter than that of women in the same group.

3. Shooting parameters of leaders in various groups were significantly better than the group average.

\section{REFERENCES}

Cholewa, J., Gerasimuk, D., Michal, S., Zajac, A. (2005). Analysis of structure of the biathlon runs. Acta Universitatis Palackianae Olomucensis. Gymnica, 35 (1), 35-42.

Cholewa, J., Gerasimuk, D., Zajac, A. (2004). Trends in shooting results of elite biathletes. Journal of Human Kinetics, 12, 155-162.

Grebot, C., Burtheret, A. (2007). Effects of temperature changes on the mechanical and ballistic responses in biathlon shooting. American Society of Mechanical Engineers, 74 (5), 137-142.

Grebot, C., Groslambert, A., Pernin, J. N., Burtheret, A., Rouillon, J. D. (2003). Effects of exercise on perceptual estimation and short-term recall of shooting performance in a biathlon. Perceptual and Motor Skills, 97 (2), 1107-1114.

Hofman, M. D., Gilson, P. M., Westenburg, T. M., Spences, W. A. (1992). Biathlon shooting performance after exercise of different intensities. International Journal of Sports Medicine, 13 (30), 270-273.

Hofman, M. D., Street, G. M. (1992). Characterization of the heart rate response during biathlon. International Journal of Sports Medicine, 13 (5), 390-394.

Hora2000. Professional biathlon target system. Shooting analysis protocols. Internet link: http://www.hora2000. de/en/downloads/.

International Biathlon Union. Official protocols of Biathlon World Championships. Internet link: http:// services. biathlonresults.com/Schedule.spsx.

Kryl, A. (1987). Vyuiti dynamometri poi kontrole trnovanosti vrcholovych biatlonistu. Zpravodaj videcke rady UV Scazarmu, 3, 12-24.

Manfredini, F., Manfredini, R., Carrabre, J. E. et al. (2002). Competition load and stress in sports: A preliminary study in biathlon. International Journal of Sports Medicine, 5, 348-352.

Nitzsche, K. (1998). Biathlon: Leistung - Training Wettkampf - Wiesbaden: Limpert Verlag GmbH, 4-5, 23-65.

Paugachova, B. (2000). Teoria a metodika portovej pripravy v biatlone. Banska Psychology, 3, 197-221.

Paugschova, B., Gerekova, J., Ondraček, K. (2010). Biorythmic changes in the development of velocity and power abilities in biathlon. Studia sportiva, 4 (1), 25-34. Pöhlmen, R. (1986). Motorishes Lernen, psychomotorishe Grundlagen der Handlungsregulation sowie Lernprozessgestalung im Sport, 28-55.

Pustovrh, J., Jost, B., Vodicar, J. (1995). Analysis of the structure of competitive successfulness in biathlon. Acta Kinesiologiae Universitatis Tartuensis, 171-185.

Rundell, K., Bacharach, D. (1995). Physiological characteristics and performance of top U.S. biathletes. Medicine and Science in Sports and Exercise, 9, 13021310.

Sattlecker, G., Müller, E., Lindinger, S. (2006). Performance determining factors in Biathlon shooting: 12th Annual Congress of the ECSS, Jyväskylä, Finland 11-14.

Skernevičius, J., Čepulènas, A., Milašius, K., Dadelienė, R. (2005). Slidinejimas. Vilnius.

Сорокина, А. В. (2010). Технология психологопедагогического сопровождения стрелковой подготовки биатлонистов в ДЮСШ: автореф. дисс. Тюмень.

Шикунов, М. И. (1987). Тактичесская подготовка высококвалифицированных биатлонистов разного возраста на основе имитационного моделирования соревновательной деятельности: автореф. дисс. к. $n$. н. Москва. 


\title{
SKIRTINGŲ AMŽIAUS GRUPIŲ BIATLONININKŲ 2011-2012 METU PASAULIO BIATLONO ČEMPIONATŲ ŠAUDYMO RODIKLIAI
}

\author{
Lina Kreivènaitė \\ Lietuvos edukologijos universitetas, Vilnius, Lietuva
}

\section{SANTRAUKA}

Tyrimo pagrindimas ir hipotezè. Biatlonininkų fizinio parengtumo problemos yra gana plačiai išnagrinètos, tačiau biatlono šaudymo klausimai Lietuvoje nėra analizuoti. Specialiojoje pasaulinèje literatūroje trūksta informacijos apie tai, kokių šaudymo rodikliu pasiekia pasaulio biatlono čempionatuose lyderių pozicijas užimantys biatlonininkai. Šaudymo rodikliai neišanalizuoti ir skirtingų amžiaus grupių bei lyčių požiūriu. Tyrimu tikrinama hipotezè, kad suaugusiujų biatlonininkų šaudymo rodikliai skiriasi nuo jaunimo ir jaunių amžiaus grupių biatlonininkų.

Tikslas - išanalizuoti suaugusiujų, jaunimo ir jaunių biatlonininkų 2011-2012 metų pasaulio čempionatu šaudymo rodiklius ir juos palyginti lyties bei amžiaus požiūriu.

Metodai. Duomenų analizei pasirinkti jaunių (amžius: 17-18 m.), jaunimo (amžius: 19-20 m.) ir suaugusiujų (amžius: 21-41 m.) grupių biatlonininkų šaudymo rodikliai. Analizuoti tokie šaudymo rodikliai: laikas ir taiklumas. Stebėjimo vienetų kiekis 2011-2012 m. $-\mathrm{n}=2175$. Duomenų analizei atlikti taikyti matematinès statistikos metodai.

Rezultatai. Nustatyti suaugusiuju, jaunimo ir jaunių amžiaus grupių biatlonininkų šaudymo rodikliai buvo palyginti lyčių bei amžiaus požiūriu. Taip pat palyginti skirtingo amžiaus biatlonininkų šaudymo rodikliai su atitinkamoje grupèje lyderiu pozicijas užèmusių biatlonininkų šaudymo rodikliais.

Aptarimas ir išvados. Nustatyta, kad biatlonininkių moterų šaudymo taiklumas jaunių ir jaunuoliu amžiaus grupèse yra didesnis nei atitinkamos grupės biatlonininkų vyrų $(p<0,05)$. Suaugusiuju grupių biatlonininkų taiklumas didesnis nei jaunimo ir jaunių ( $<<0,025)$. Šaudymo laiko vidurkis ilgiausias jaunių amžiaus grupejje. Suaugusiujų grupès biatlonininkai šūvius atlieka per trumpiausią laiko tarpą $(\mathrm{p}<0,001)$. Jaunių, jaunimo ir suaugusiujų vyru grupių biatlonininku šaudymo laiko vidurkis yra trumpesnis nei moterų atitinkamai $(p<0,05)$. Lyderiu pozicijas iškovojusių biatlonininkų šaudymo parametrai reikšmingai skyrèsi nuo atitinkamos grupės vidurkio $(p<0,05)$.

Raktažodžiai: biatlonas, šaudymo taiklumas, šaudymo laikas. 